\title{
ANOTHER SIDE OF ISLAM IN BANTEN The Socio-Political Roles of Jawara during the New Order Era 1966-1998'
}

\author{
Yanwar Pribadi \\ IAIN Sultan Maulana Hasanuddin, Banten - Indonesia
}

\begin{abstract}
This paper deals with the socio-political roles of jawara in Banten as both traditional and modern leaders during the New Order period 1966-1998. This paper shows that Banten is not only an area of piety, but also an area of tradition and violence in different forms. In the colonial period, jawara mounted resistance-along with ulamaaimed at overthrowing not only existing political regimes but also the socio-cultural order as it then existed. During the New Order, this development was altered with the cooptation of both ulama and jawara by Golkar. By envolving to the state and adjusting to the new atmosphere of the political situation, jawara and ulama created new positions where they gradually expanded their power, status and wealth. Throughout the Suharto's power, they demonstrated the patron-client relationships with the government.
\end{abstract}

Keywords: Jawara, power relations, ulama, local politics.

\section{Introduction}

Banten is a religiously associated region, like Aceh and Madura, where the society is traditionally linked to a religious world view. It has many traditions and customs linked with religion. Banten is wellknown for its long history of mysticism and rebellion, as well as the Islamic orientation of its society. After Banten occupied by the Dutch, three forms of informal leadership emerged in Bantenese society. The first was the traditional aristocracy (priyayi). The others were ulama and

\footnotetext{
1 Most parts of this paper are taken from my M.A. thesis at Leiden University, the Netherlands, while some parts are elaborated later.
} 
jawara. ${ }^{2}$ Of these three, the latter two still exist until today, even they have the most important role in society, both during the colonial period and after Indonesian independence (the Old Order and the New Order, and Reform Era).

Throughout history, jawara ${ }^{3}$ in Banten have displayed a long continuity in the various roles, from their mythical origins as bodyguards of kings and ulama, as instigators of rebellions, as criminals, as village heads, to their mobilisation as security personnel for political parties and the ruling elite. According to Sartono Kartodirdjo, the jawara consisted largely of people without permanent occupation who were often engaged in criminal activities. ${ }^{4}$ Resident F.G. Putman Craemer, in his memorie van overgave (memorandum of Dutch officials at the end of their term in office), wrote that jawara originally evolved from Orok Lanjang, a youth organization in the district of Menes. This organization then developed, spread outside Menes and became a bodyguard organization that was notorious for being involved in fighting and stirring up trouble (ANRI, 1980: XXIII). ${ }^{5}$ In fact, the colonial government considered jawara as bandits,

\footnotetext{
${ }^{2}$ In Indonesian society, the word ulama may be used arbitrarily to refer to kiai. In Banten, the term kiai also means leadership and other non-religious realms. In a broader context the term ulama refers to Islamic scholars and to Islamic religious leaders. Hence, this paper uses both terms, ulama and kiai, interchangeably. Moreover, in Indonesia, the term kiai and ulama can be used as both singular and plural forms. Other non-English terms in this paper can be used as both singular and plural forms as well.
}

3 Jawara, in one way or another, have become the object of a number of studies. Sunatra (1997) wrote about the political positions of ulama and jawara. H.S. Suhaedi (2006) was concerned with the social mobility of jawara. Ahmad Abrori (2003) spoke about the political behaviour of jawara, while M.A. Tihami (1992) was concerned with the leadership of jawara in Banten. The notorious position jawara occupied in society was also dealt with by Atu Karomah (2004), who spoke about the culture of violence in Banten society. Furthermore, Syarif Hidayat (2003) dealt with Tuan Besar (literally Mr. Big), the autonomous hegemony of Tubagus Chasan Sochib and Okamoto Masaaki and Abdul Hamid (2008) were concerned with the power of jawara after the fall of Suharto.

${ }^{4}$ Sartono Kartodirdjo, The Peasants 'Revolt of Banten in 1888, Its Conditions, Course, and Sequel: A Case Study of Social Movements in Indonesia (Gravenhage: Martinus Nijhoff, 1966), pp. 57-58.

${ }^{5}$ Furthermore, Michael Williams stated that this organization was originally a mutual aid society which had its own administration, treasurer and local branches. Some branches had their own president and secretary with members paying monthly 
so that all social oppositional movements against government were considered to be onlusten (disturbances), ongeregeldheden (revolts), complot (conspiracies), woelingen (disorders), or onrust (unrests). ${ }^{6}$ Both Kartodirdjo and Craemer classified jawara as a negative social group. This paper argues that the jawara have played a crucial role in the New Order Era as the main proponent of the regime in the local political culture.

The paper is concerned with the roles of jawara in Banten during the New Order Era 1966-1998. It aims to elucidate the socio-political roles of jawara in the New Order Era. Regarding this, the study focuses on the following questions: what is the background of the emergence of jawara? What roles do jawara play in Banten in the New Order Era? How do jawara build the relationship with ulama and society?

\section{The Background to the Emergence of Jawara}

In general, Banten has two different geographical characteristics. The southern part is mainly upland and sparsely populated, while the northern part is more apt to be lowland and is densely populated. Most inhabitants in Banten are Sundanese, who reside in the southern part. Others are Javanese and Baduy or Kanekes. Javanese, who originally come from Demak and Cirebon, live mostly in the northern part. While Kanekes or Baduy ${ }^{7}$ people, develop their own culture and live in the mountain area in the southern part. ${ }^{8}$

contributions. See, Michael Williams, Communism, Religion and Revolt in Banten (Athens: Ohio University Center for International Studies, 1990), p. 281.

${ }^{6}$ Nina Lubis, Banten dalam Lintasan Sejarah: Pergumulan antara Ulama dan Jawara (Jakarta: LP3ES, 2004), p. 128.

${ }^{7}$ For the position of Baduy people vis-a-vis the rest of the population of West Java, see Robert Wessing, "The Position of the Baduj in the Larger West Javanese Society," Man, Vol. 12, No. 2 (1977): pp. 293-303.

8 Kartodirdjo pointed out that the differences between North and South Banten should be ascribed partly to the differences in natural environment, an ecological factor, as well as to differences of a socio-cultural or historical nature. See, Kartodirdjo, The Peasants` Revolt of Banten, p. 30. Generally speaking, these three ethnic groups (the Sundanese, the Javanese, and the Baduy) have shown distinctions in language and custom. For instance, among the Dutch, the North Bantenese were notorious for their religious fanaticism, their aggressive attitude, and their rebellious spirit. Meanwhile, paying attention to the distinction in language, Moriyama Mikihiro argued that the self-awareness of being distinct in terms of language, culture, and ethnicity did not exist in West Java before the nineteenth century. It was colonial administrators and scholars who forced the people of West Java to objectify 
The inland region of Banten is more fertile. The north, especially the coastal region, where the hills gradually slope downwards, is characterised by poorly irrigated rice fields, a relatively high incidence of crop failure, and the almost complete absence of any crop other than rice. ${ }^{9}$ However, Kartodirdjo has different opinion. According to him, the most irrigable rice field was in the mountain slopes and the plains in the north. Therefore, the domains of the Sultan located in the northern plain. Meanwhile, the mountainous and hilly regions in the south are regions where dry-rice are cultivated. Moreover, he points out that this region is dry and non-irrigable. ${ }^{10}$ It seems that the different perspective between these two authors concerning the fertility of Banten region lies on the changing appearance in Banten's rice fields over time. It is also interesting to note that according to archaeologist, Heriyanti Untoro, there have been changes in the environment caused by the exploitation of clay for the making of earthenware vessels for hundreds of years. ${ }^{11}$

Moreover, according to Kartodirdjo, social system in Bantenese society is determined by social stratification called undakan. There is a popular opinion that Bantenese society is usually conceived of as presenting a bi-modal class division. The majority of people comprises peasants, craftsmen, traders, and labourers are djalma leutik. The word orang tani is largely used for the social classification of people who made a livelihood by becoming tillers, craftsmen, and traders, while fishermen are not included. Meanwhile, a small upper class consists of bureaucratic elite and nobility called priyayi. ${ }^{12}$

This categorization is somewhat incorrect since orang tani can also be considered as djalma leutik. Both of them are in a lower class compared to priyayi. Therefore, the division consisted of djalma leutik or

themselves in opposition to the Javanese and the Malay, cited in Ota Atsushi, Changes of Regime and Social Dynamics in West Java: Society, State and the Outer World of Banten 17501830 (Leiden and Boston: Brill., 2006), p. 174.

9 Williams even suggested that Pandeglang in the South was the most fertile region in Banten. See, Williams, Communism, Religion and Revolt in Banten, pp. 2-4.

${ }^{10}$ Furthermore, he stated that economic factors favoured the North, which comprised the main granaries and was located to trade routes and centres. See, Kartodirdjo, The Peasants 'Revolt of Banten, p. 31.

${ }^{11}$ Heriyanti O. Untoro, Kebesaran dan Tragedi Kota Banten (Jakarta: Yayasan Kota Kita, 2006), p. 129.

${ }^{12}$ Kartodirdjo, The Peasants 'Revolt of Banten, p. 50. 
orang tani, and priyayi. Special attention must be paid to two prominent groups of the peasantry, the village authorities and the religious leaders, who formed the rural elite. Kartodirdjo suggests that social roles and attendant status within the village are clearly important. In the social movement, the religious leaders play an essential role, in which a special regard should be addressed to these leaders. ${ }^{13}$

Kartodirdjo's depiction of the rural elite is obviously important in providing background to the emergence of the jawara. ${ }^{14}$ During the sultanate period, the village head was appointed by the sultan or by the appanage holder, to which land in the village was granted as pecaton (land granted to relative's officials, and personal favourites of the sultan). In one village usually there were several jaro (village head) ${ }^{15}$, each jaro represented his master, who had gotten land as pecaton. It is interesting to note that from the annexation of Banten up to 1844, the jaro seemed to have been appointed by the government on the basis of suggestions made by the village elders, or by the demang (district head in Banten and Batavia in the nineteenth century); as from 1844, the jaro were elected by the people and the choice afterwards sanctioned by the government. The main function of the jaro was a mediator between the local population and the broader administrative system. However, the jaro was regarded neither as a representative of the village inhabitants, nor as the real authority in their realm. The colonial government regarded the jaro as a weak link in the colonial administrative chain between the central government and the village.

\footnotetext{
13 Ibid., p. 54.

14 Williams and Atsushi have suggested that scholars who deal with the early nineteenth century Banten, especially the socio-economic and socio-political situation in that period, should consult Kartodirdjo `s work. Therefore, I am stimulated by these scholars in presenting the background to the emergence of jawara. Williams, Communism, Religion and Revolt in Banten, p. 3 and Atsushi, Changes of Regime, p. 10.

${ }^{15}$ In Colonial Java, the Dutch created new villages and gave the headmen power over villagers they previously did not have. Moreover, the Dutch named the village headmen 'lurah', a sacred position derived from the wayang (shadow puppet) tradition in Javanese popular culture. For historian Onghokham, the title of village headmen in pre-colonial Java seems not to have been lurah but bekel demang or petinggi patub; they functioned chiefly as tax-collectors and organizers of labour. See, Onghokham, "The Jago in Colonial Java, Ambivalent Champion of the People," in Andrew Turton and Shigeharu Tanabe (eds), History and Peasant Consciousness in South East Asia (Osaka: National Museum of Ethnology, 1984), p. 335.
} 
Furthermore, Kartodirdjo suggests that there are at least four social groups which cut across the village hierarchy. The first is the kolot-kolot (the elders), who enjoy authority over the villagers, because they performed a ceremonial function in the village administration. The panghulu (head of mosque functionaries) or amil (village official in charge of collecting rakat), should be regarded as the second one. His power often surpassed that of the jaro. Last but not least, two more groups may be pointed out are the religious men and the jawara. The group of religious men (kiai and haji) are of high rank and should be regarded as socially prestigious in Banten, where almost everyone is a Muslim. The last group-the jawara-shall be discussed later. ${ }^{16}$ Different with Kartodirdjo, Williams only points out three groups that dominate rural life in particular. They are the ulama, local notables, and the jawara.

Kartodirdjo believes that the jawara consisted of people without permanent occupation, often engaged in criminal activities. Whereas Williams and Atsushi have a more positive view of them. Williams states that jawara are peasants, usually unattached young men, who led a semi-outlaw existence and whose influence and prestige are often far greater than official headmen. Atsushi sees jawara in almost the same way as Williams. According to him, jawara are not only local strongmen, whose influence and prestige are often far greater than those of the official headmen in remote areas of Banten throughout the colonial period, but he also associates jawara with the phenomenon of the social bandit throughout the world, in the nineteenth and the twentieth century, and with jago (local strongmen in colonial Java). ${ }^{17}$

In principle, it can be argued that the emergence of jawara is not a result of sheer oppression and grinding poverty in Banten. Though they may have joined in spontaneous food riots, or may have committed criminal acts, people facing starvation are too busy merely surviving to plot the overthrowing of government or to formulate a blueprint for an alternative social order. ${ }^{18}$ The emergence of the jawara supports this proposition and the assertion that the potential for

\footnotetext{
${ }^{16}$ Kartodirdjo, The Peasants` Revolt of Banten, pp. 54-58.

17 See, Ibid., pp. 57-58; Atsushi, Changes of Regime, p. 154; and Williams, Communism, Religion, p. 45.

${ }^{18}$ Eric Hobsbawn, Primitive Rebels: Studies in Archaic Forms of Social Movement in the 19th and 20th Centuries (Manchester: Manchester University Press, 1959), p. 79.
} 
violent social protest corresponds to relative rather than absolute deprivation. Jawara groups who are considered to be bandits reduced to starvation or to total impoverishment; they suffered a significant decline in their social standing and economic well-being.

In the colonial period, a considerable number of jawara started off as poor peasants who drifted back and forth between the countryside and the towns, or who had no land. Meanwhile, others were simply young men who depended on petty crime as an easier source of income than tilling the soil, or, in times of hardship, as a necessary addition to their income. They had an ambiguous relationship with the rural population; they were both feared and admired. Some exercised a virtual reign of terror in their regions, but others were seen as champions of peasant rights for their struggle against the Dutch and the priyayi. ${ }^{19}$

\section{Banten during the New Order}

According to Michael van Langenberg, the New Order is both state and state system. While the state is an entity, an arena, and an idea, while the state system is made up of executive government, military, police, parliament, bureaucracy and courts. Thus the state system can be perceived as a network of institutions, by means of which the rulers of a government attempt to control civil society and manipulate the means of production, distribution and exchange, in pursuance of declared national and community interests. ${ }^{20}$

Moreover, Richard Robison suggests that the major indigenous business groups in the New Order Era could be divided into three categories: the survivors from the 1950s, the 'politico-bureaucrats' of the New Order who established business groups based largely on preferential access to government contracts and licences, and the 'new capitalists' who emerged over the 1970s and 1980s on the basis of their entrepreneurial abilities. ${ }^{21}$ Nevertheless, the most striking fact about these groups was that they were conglomerates controlled by members of the Suharto family. Many of the large Chinese-owned

\footnotetext{
${ }^{19}$ Williams, Communism, Religion, p. 46.

${ }^{20}$ Michael van Langenberg, "The New Order State: Language, Ideology, Hegemony," in Arief Budiman (ed.), State and Civil Society in Indonesia (Clayton: Monash University Centre for Southeast Asian Studies, 1994), p. 122.

${ }^{21}$ Richard Robison, Indonesia: The Rise of Capital (Sydney: Allen and Unwin, 1986), p. 329.
} 
conglomerates of recent provenance were known to have strong links to high government officials and their immediate families. While the new breed of corporate tycoon which emerged under the New Order, whether Chinese or indigenous, still relied on family ties to secure their business. $^{22}$

In general, the situation as sketched above, holds true in any region in Indonesia, including in Banten. With the enactment of Law No. 5/1974 on Government in the Regions, the New Order regime reduced Banten to one of several regencies under the Province of West Java. This brought with it many disadvantages. Until the reign of the New Order came to an end, Banten had the lowest levels of education and public welfare in West Java. Moreover, Banten had a high number of 'backward villages' as well. ${ }^{23}$

\section{Jawara as Politicians and Entrepreneurs}

Under the New Order the political domination of the state over society extended enormously. Suharto and his supporters, especially the armed forces, moved to limit political participation and to concentrate power. In a range of different ways the scope for societal groups to influence the content and direction of public policy was reduced as the government set about a massive restructuring of the country's political landscape. Political parties and interest groups were tamed and brought within a central corporatist framework of statedominated political management. Moreover, as the New Order became more established, societal input was increasingly excluded, with control over policy coming to be monopolised by state officials. The government seemed to be able to rely on the armed forces to contain and suppress any unrest. The New Order then became a military-based regime with a developmental orientation that was characterised by a high level of state control over politics and policy. ${ }^{24}$

In Banten, ulama and jawara were co-opted into the political machines of Golkar. The recognition of ulama by the governing party

\footnotetext{
22 Anne Booth, The Indonesian Economy in the Nineteenth and Twentieth Centuries: a History of Missed Opportunities (Canberra: The Australian National University, 1998), pp. 318-320.

${ }^{23}$ Syarif Hidayat, "'Shadow State'?: Business and Politics in the Province of Banten," in Henk Schulte Nordholt and Gerry van Klinken (eds), Renegotiating Boundaries: Local Politics in Post-Subarto Indonesia (Leiden: KITLV Press, 2007), p. 206.

24 Andrew Macintyre, Business and Politics in Indonesia (North Sydney, NSW: Allen and Unwin, Macintyre, 1991), pp. 2-3.
} 
was manifested by the establishment of Satkar Ulama in 1971, while jawara were organised into Satkar Pendekar (the Martial Art Work Squad) in 1972. By involving to the state and adjusting to the new atmosphere of the political situation, they created new positions where they gradually expanded their power, status and wealth and developed patron-client relationships.

The patron-client relationships in Banten in the New Order era perhaps were best identified in the ties between the state and jawara. Throughout history, jawara always work individually or in small bands. Whilst there were informal networks of individual jawara, usually based upon allegiances and loyalties to particular ulama, there had never been a formal structured organization. Satkar Pendekar, renamed Persatuan Pendekar Persilatan dan Seni Budaya Banten Indonesia (PPPSBBI-the Indonesian Association of Bantenese Men of Martial Arts, Art and Culture), was established as a forum for jawara and martial arts schools throughout Banten as well as those in Jakarta. From its inception PPPSBBI identified "nation and state" with Golkar, with whom they had had a close relationship since the 1977 general election. It was largely due to the influence of Tubagus Chasan Sochib who, since the early 1970s, was a local parliamentarian for the Golkar faction, and certainly a prominent figure in the jawara community. 25

Sochib was born in Serang in 1930 and died in Serang in 2011. He had three brothers, Tubagus Basuni, Tubagus Syatibi and Entus Sibli, and one sister, Ojah Faojah. They are all children of Tubagus Sochib and Nyi Ratu Rofiah. He attended several pesantren (Islamic boarding school) during his childhood. One of the pesantren, the Pesantren Pani is in Jiput, Pandeglang was his first boarding school. He was entrusted to Kiai Cholil by his parents. During his stay, he showed braveness and intelligence, an attitude which would benefit his future career in many areas of society. In the revolutionary era, Sochib went to Pesantren Cadasari, under the guidance of Kiai Icot. Shortly after the acceptance to that pesantren, he joined Hisbullah, a guerrilla warfare unit, whose commanders were Kiai Abdullah and Ayip Samin. After the revolutionary period came to an end, he embarked upon a more serious working life in 1967 (after a couple of years dealing with a

\footnotetext{
${ }^{25}$ Ian Douglas Wilson, The Politics of Inner Power: The Practice of Pencak Silat in West Java (Unpublished Ph.D. thesis, Murdoch University, 2003), pp. 257-258; Okamoto Masaaki, "Local Politics in Decentralised Indonesia: the Governor General of Banten Province," ILAS Newsletter, No. 34 (2004), p. 23.
} 
number of small businesses) by providing logistical support to the Kodam Siliwangi (the regional army forces of West Java). Two years later he founded a construction company, P.T. Sinar Ciomas Raya, which frequently won government tenders for road and market construction projects. His involvement spread to the Krakatau Steel State Company, and to tourism and real estate, while holding key positions in associations, such as the Regional and Central Chambers of Commerce and Trade (Kamar Dagang dan Industri - Kadin) and the Indonesian National Contractor's Association (Gabungan Pengusaha Nasional Indonesia - Gapensi), putting his men on their local executive committees. ${ }^{26}$

The position of Sochib in the PPPSBBI as chairman was the peak of his vertical mobility. That he was a kepala kuli (chief labourer) and then gained a more respectable status by becoming an entrepreneur showed this mobility. After he had reached the top, he moved horizontally, increasing his social mobility. Even though PPPSBBI is not a wing organization of Golkar, the organization was essential in the political context of Golkar. Golkar was a crucial and strategic element for Sochib in expanding his horizontal mobility. As a man with power-both social power and power through violence-through Golkar he had a wide sphere to increase his political access. To strengthen his domination in Golkar, he placed jawara as cadres in the organization with the banyan tree as its symbol. These cadres held several important positions at the district and municipal levels. Apparently, those who had had experience as local officials were favoured by him. However, according to H.S. Suhaedi, to be actively engaged in Golkar was not his choice in career, although in reality he was a member of the advisory board. For Sochib, Golkar was an instrument to expand and secure his business, not mainly a tool to obtain political power. Therefore, through Kadin and Gapensi, Sochib could control the companies operated in Banten, due to the fact that certifications from Kadin and Gapensi were necessary for government procurement. Sochib utilized this to coordinate projects in Banten and the coordination brought him more money. Another side to this situation is that it led jawara under his control to become his (sub) contractors and receive a share of his profits. ${ }^{27}$

26 Ibid.; Khatib Mansur, Profil Haji Tubagus Chasan Sochib beserta Komentar 100 Tokoh Masyarakat Seputar Pendekar Banten (Jakarta: Pustaka Antara Utama, 2000), pp. 79-82.

${ }^{27}$ Masaaki, "Local Politics in Decentralised Indonesia", p. 23. 
Nevertheless, I would argue that the PPPSBBI is the first organization to spread his power in the political constellation, and that the political constellation was the vehicle introducing him to a bigger business world than he had moved in before. One of the main purposes of the establishment of the PPPSBBI was to channel the aspirations of jawara away from self-interest and criminality towards more 'constructive' activities, that contributed to the New Order's programme of social and economic development. Encompassing over 70 perguruan (martial art schools) and debus (traditional Bantenese invulnerability performance) groups, by the mid 1990s the organization claimed a membership of 170,000. In the words of Sochib, "in the past jawara only fought for themselves, their group or tribe, however via the PPPSBBI together we fight for the nation and the state". Commonly known as jawara pembangunan (development jawara), they worked to ensure Golkar's supremacy. Taking advantage of the long-standing influence of jawara in village life, Golkar, through the General Ali Murtopo, utilized PPPSBBI to secure support for the party in Banten. In addition, as the general chairman of the pendekar ${ }^{28}$ organization and one of the executive committee members of Satkar Ulama, Sochib could become a mediator among the military, bureaucracy and Golkar, as well as the informal world of Banten. ${ }^{29}$

In part due to the close connection of jawara with traditional custom, Golkar cadres in general elections that had jawara support were guaranteed of victory, for to oppose jawara meant facing the powerful magic of the ancestors. Their orders, usually in the form of a threat, were always followed by villagers, whom nevertheless had a faith in their ability to get things done. Seen in the context of the political landscape of the time, the establishment of the PPPSBBI coincided with a drive by the New Order to consolidate its power. It seems that this is the way they institutionalized troublesome groups and subcultures such as jawara. In the name of promoting 'development', PPPSBBI became field agents of the New Order. ${ }^{30}$

\footnotetext{
28 In order to avoid the negative image that had come to be associated with the term jawara, it was replaced with 'pendekar'. See, Wilson, The Politics of Inner Power, p 258. However, Tihami who conducted research into jawara in 1992 did not agree with the term pendekar, due to the non-originality of the word pendekar in Bantenese languages. See the interview with Tihami in Mansur, Profil Haji Tubagus Chasan Sochib, p. 268.

${ }^{29}$ Wilson, The Politics of Inner Power, p. 258.

${ }^{30}$ Ibid., pp. 258-259.
} 
Nevertheless, Sochib was not only a jawara and a businessman, but he was also a founder of Universitas Sultan Ageng Tirtayasa (Untirta) ${ }^{31}$, Sekolah Tinggi Agama Islam Syekh Mansyur (Staisman), the Banten Museum, and the head of the Serang branch of Generation 45. He had become powerful in all aspects of Bantenese life; thus many top bureaucrats relied on him and his networks as a bridge to the Bantenese world. 32

Another prominent jawara figure in Bantenese society is Maman Rizal. Like many other jawara, after mastering martial arts, he went to Jakarta to gain better chances for his livelihood. In 1967 he began his political career by entering Sekber (Sekretaris Bersama/the joint secretary) Golkar. In 1970, he joined the MKGR (Musyawarah Kekeluargaan Gotong Royong/The Mutual Assistance Families Society), a wing organization of Golkar. After returning to Banten, he became a member of the Pandeglang branch of Golkar. In Pandeglang he was appointed as Ketua Divisi Pemenangan Pemilu dan Pengkaderan (the Head of Winning the General Election and Forming of Cadres Division or simply the Success Team) of Golkar in 1987-1988. His wide network was a basic reason for holding several important positions in Golkar.

In addition, he also served as the treasurer of MKGR from 1975 until 1987. His political career in Golkar gradually improved with his appointment as treasurer of the Serang branch of Golkar, from 19882000. For Rizal, Golkar had political and economical benefits that formed a structural base for broadening his power. As an entrepreneur, he has become involved in many government-financed projects. Meanwhile, in the jawara world, he is now a leading figure in the Kebudayaan Seni Tari dan Silat Indonesia Tjimande Tari Kolot Kebon Djeruke Hilir (Kesti TTKKDH-the Indonesian Dancing and Martial Arts Tjimande Tari Kolot Kebon Djeruk Hilir Association). ${ }^{33}$ This organization is widely known among the Bantenese, and thus facilitates

\footnotetext{
${ }^{31}$ Recently, following the formation of Banten as a separated province from West Java province, the university was transformed to a state university.

32 Masaaki, "Local Politics in Decentralised Indonesia", p. 23; H.S. Suhaedi, Jawara Banten: Kajian Sosial-Historis tentang Mobilitas Sosial Jawara (Unpublished M.A. thesis, Universitas Indonesia, 2006), p. 135.

33 This organization is an umbrella organization which covers all Cimande martial arts schools and was established in 1952 and claims to have approximately 10 millions members all over the country. The number of the members seems very much to be exaggerated.
} 
spreading the organization to villages. Consequently, Kesti TTKKDH contributed to the victories of Golkar in general elections during the New Order era. In short, like Sochib, the economical aspect is a main reason behind Rizal's activities. ${ }^{34}$

Moreover, Robison demonstrates that one characteristic of political power in post-colonial Indonesia was that offices of authority within the political parties and the civil and military bureaucracies had generally been monopolized by relatively small groups. ${ }^{35}$ In Banten, these relatively small groups were led by jawara. The two examples of prominent jawara and their companies show us that jawara to a large extent held important roles in colouring the socio-political aspects of Bantenese life. Furthermore, despite their dependence on the central government, regional governments were relatively powerful in terms of local administration because they offered employment and channelled government funds. This facilitated the reproduction of patrimonial patterns of rule at the local level, especially in Banten. Even though jawara as the local elite had access to central state agencies, they also relied on local constituencies that were mobilized through ethnic loyalties. The Suharto administration offered them the opportunity to expand and maintain regional networks of patron-client ties.

It is interesting to note that Sochib was also involved in Kamar Dagang dan Industri (Kadin) and Golkar, whereas Rizal was only in Golkar. According to Andrew Macintyre, among the business community, Kadin was seen too close to the government. In particular, the Kadin leadership was seen as being inappropriately close to Golkar. Prominent Kadin figures frequently offered open support and endorsement of Golkar and the government. ${ }^{36}$ Their involvement in the ruling party was needed for procuring government contracts. Sochib used this to coordinate contracts from the government in the Banten area, while Rizal benefited in order to increase his domination of power. However, as described earlier, jawara were also notorious for

\footnotetext{
34 Suhaedi, Jawara Banten, pp. 137-140.

35 Richard Robison, "Culture, Politics, and Economy in the Political History of the New Order," in Benedict Anderson and Audrey Kahin (eds). Interpreting Indonesian Politics: Thirteen Contributions to the Debate (Ithaca: Cornell Modern Indonesia Project Cornell University, 1982), pp. 138-9.

36 Andrew Macintyre, "State-Society Relations in New Order Indonesia: the Case of Business," in Arief Budiman (ed.), State and Civil Society in Indonesia (Clayton: Monash University Centre for Southeast Asian Studies, 1994), pp. 376-377.
} 
their involvement in criminal activities; as businessmen with a tremendous interest in obtaining access to the resources controlled by local government, they made maximum use of their dual status (as pure jawara who rely solely on their martial arts ability and as businessmen). As businessmen, they maximized their financial resources and as jawara they used their resources of force.

To strengthen their domination of power, jawara also had strong control over the press and the institutions of higher learning in Banten. Neither was able to play their roles as public watchmen, because to a large extent they were either under pressure or benefited from the jawara's activities. To weaken the level of criticism of the press, jawara who were actively involved in both local parliament and government, and entrepreneurs as well, frequently bestowed the editorial elite with government projects, such as research and book publications. Having money was also a way to discourage the critical quality of the institutions of higher learning. Since they acted both as founders and as providers of funds for the institutions, jawara were seen as guardian angels, making the institutions' intellectual element reluctant to criticize jawara.

The roots of the New Order business-military alliance laid in the revolutionary period, through military commander Suharto's financial arrangements with Chinese businessmen. ${ }^{37}$ Furthermore, the major indigenous capitalists were not prominent in confronting foreign and Chinese capital. Indeed, their emergence under the New Order was achieved by integrating them in joint ventures, consortiums, distribution and management arrangements. Such integration was built upon public legislation which guaranteed the entry of indigenous capital into joint ventures and restricted the entry of foreign and Chinese capital into specific fields of investment. Consequently, there was little incentive for major indigenous capitalists to agitate for

\footnotetext{
37 According to Robison, the largest element of the Suharto family's corporate investments was that constituted in equity holdings in the Liem Sioe Liong group. Through Sudwikatmono, the Suharto family held five percent of the shares in the Tiga Roda cement group, four percent in the Bogasari flour milling company, and at least five percent in Waringin Kencana, the trading and rubber milling firm. Sigit Harjoyudanto and Siti Hardijanti held thirty two percent of the Bank Central Asia, the largest private foreign-exchange bank. Sudwikatmono was also President Director of Waringin, Indocement and Bogasari. See, Robison, Indonesia: The Rise of Capital, p. 346. To a large degree, however, this information is doubtful, since no one really knows about the wealth of Suharto.
} 
political power, as a class, when the military ruled so effectively in their interest. At the same time there was no reason whatever for the major indigenous capitalists to put any real venom into campaigns against foreign or Chinese capital, while they were guaranteed a stake in the growth of these groups. For instance, there were some close connections between William Soerjadjaja (Tjia Kian Liong), a Chinese capitalist, and Ibnu Sutowo, Sjarnubi Said and Moh. Joesoef (the last two were indigenous entrepreneurs). They were all Soerjadjaja`s partners as sole agent of Daihatsu and of Honda motorcycles, in PT Inter Astra Motors, as well as in other companies. In addition, Liem Sioe Liong, another Chinese capitalist, also developed a broad range of partnerships with domestic private and public business groups, including the state-owned Krakatau Steel, the Ciputra property construction manufacturing group, Sukamdani Sahid`s group, and the Suharto family. ${ }^{38}$

The same situation also existed in Banten. Sochib worked for a Chinese entrepreneur, Tek Wat, in the early 1950s. Tek Wat was a merchant who ran a business in agricultural products. When Sochib worked for him in 1954, he frequently travelled to Sumatra as Tek Wat's right-hand man. In addition, he also worked for another Chinese entrepreneur, Tek Bo. Furthermore, he got an opportunity to cooperate with a South Koreans contractor, Lee, who was working in Indonesia, building the Jakarta-Merak toll road. He was entrusted with being a subcontractor supplying all materials for the project. The cooperation was successful. After the project was finished, he was granted one unit of Asphalt Mixing Plant (AMP) for minor compensation. Up to now, PT Sinar Ciomas Raya is the most fully equipped contractor company in Banten. ${ }^{39}$

It seems that avoiding confronting foreign and Chinese capital was wiser for Sochib than competing with them. Such cooperation indeed led Sochib to enjoy success. On the one hand, the New Order created a strong base for jawara to enter into a mutually beneficial relationship with Golkar and the military power. The jawara leadership, supported by the Bantenese cultural structure, were used by the regime to win at Banten region. On the other hand, with Golkar endorsements, and the close relationship with the armed forces, jawara gained benefits in the

\footnotetext{
38 Robison, Indonesia: The Rise of Capital, pp. 292-301 and pp. 363-364.

${ }^{39}$ Suhaedi, Jawara Banten, pp. 82-83 and Mansur, Profil Haji Tubagus Chasan Sochib, p. 95.
} 
form of political and economical access as structural base for their endeavours.

In general, jawara used two strategic steps to penetrate the political constellation. Firstly, they placed their intellectual cadres in Golkar. Secondly, they tried to enforce their cultural influence in Golkar. To a large extent the second strategy was successful. Although they were not the majority in Golkar, the jawara were able to relatively attained their political goals. Through their slogan "Bela Diri, Bela Bangsa, Bela Negara" (defend ourselves, defend our nation, defend our country), jawara became the foremost opponents of critical groups, such as NGOs and students. The involvement of jawara in Golkar as one of the most important elements in Banten was a great success for Golkar due to their victories in general elections.

The New Order saw jawara 'reintegrated' into the role of a rapidly mobilized civilian security force, ready to defend the interests of the state. The physical capital possessed by the jawara was a means to power. During the New Order, they became a tool of those in power. They played a significant role in the manipulative political game playing that marked the end of Suharto era, referred to by some as 'thug politics'. One significant difference between the political opportunism of jawara in colonial times and the thug politics of the 1990s was the degree to which they have been institutionalised by the state. ${ }^{40}$

\section{The Integration between Ulama, Jawara and the People}

According to M.A. Tihami, jawara are the pupils of kiai. In Banten, Kiai not only teach Islamic religious learning, but also give martial arts as one of the lessons. Pupils who are more talented in practising martial arts became known as jawara. Even though they graduated from pesantren, they still considered the kiai as their teachers. Therefore, to oppose the kiai is a serious breach of etiquette, with both social and spiritual consequences, and expulsion from pesantren is a serious form of social ostracism. On a spiritual level, a rebellious pupil runs the risk of kawalat (accursed and therefore struck down by calamity). ${ }^{41}$ Perhaps that is the reason why a considerable number of jawara believe that they are the khadam (servant) of kiai.

\footnotetext{
40 Wilson, The Politics of Inner Power, pp. 266-267.

41 M.A. Tihami, Kiai dan Jawara di Banten: Studi tentang Agama, Magi, dan Kepemimpinan di Desa Pasanggrahan Serang, Banten (Unpublished M.A. thesis, Universitas Indonesia, 1992), pp. 99-100; Wilson, The Politics of Inner Power, p. 246.
} 
The close relationship between jawara and ulama was crucial throughout the late nineteenth century, when revolts against the Dutch colonial government erupted throughout Banten, and again during the struggle for independence. Both of them were central figures in village. The relationship between them was at times troubled, as jawara, to a large extent represented pre-Islamic traditions sometimes considered to be at odds with Islam. ${ }^{42}$ Among them, there were also intermediaries known as ulama jawara. This term could be applied either to jawara who had established themselves as religious teachers, or to ulama who had mastered martial arts. In either case such figures played an important role as cultural brokers. ${ }^{43}$

Moreover, both jawara and ulama jawara in the vast network of pesantren were also influential in the spread of martial arts. Perhaps martial arts in Banten are closely intertwined with the life of tarekat (Islamic brotherhood). In some cases jawara joined tarekat as part of a sincere spiritual quest. Nevertheless, commonly, tarekat and the techniques that they were taught are means toward obtaining the various kinds of esoteric knowledge that are considered essential for success as jawara. Similarly, some martial arts teachers conducted tarekat type communal devotions.

According to Hudaeri, jawara played roles mainly with leadership aspects, such as becoming jaro (lurah - village head), jagakersa (penjaga keamanan desa - village security), martial arts teachers, and teachers of magic. ${ }^{44}$ The jaro figures, who first appeared during the reign of the Sultanate, still exist in recent days. Certainly, during the New Order era, these figures were well known for their leadership in mobilizing local villagers to vote for the ruling party in general elections. Jawara also became martial arts teachers as well as teachers of magic. Initially, these were the most obvious characteristic possessed by jawara. Within jawara culture there was also a differentiation between 'black magic' and 'white magic' jawara. Those who inherited their lineage to past jawara and sought to continue it through their own offspring were 'white', whereas those with no identifiable lineage were 'black'. The

42 Wilson, The Politics of Inner Power, p. 249.

43 Sunatra, Integrasi dan Konflik: Kedudukan Politik Ulama-Jawara dalam Budaya Politik Lokal: Studi Kasus Kepemimpinan Informal Pedesaan di Banten Selatan (Unpublished Ph.D. thesis, Universitas Padjadjaran, 1997), p. 138.

${ }^{44}$ Hudaeri, “Tasbih dan Golok” (Jakarta: The Ministry of Religious Affairs, 2002), p. 44. 
existence of a lineage was crucial to the legitimization of a jawara within his community. The lineage acted as a type of 'contract' of accountability to pre-established norms. The linking thread between the two types of jawara was the possession of supernatural power. In addition, the role of jawara which is associated with magic is as debus players. It is interesting to note that many jawara often took some verses from Qur'an, and thus they believed that the power they had originally came from kiai. 45 Nonetheless, to some extent I argue that this view is somewhat incorrect since both 'white' and 'black' jawara have used black magic up to the present day.

Although kinship within jawara culture is not as deeply rooted as within that of the ulama, it still has important elements in securing the solidarity among them, particularly in the spread of martial arts and magic teachings. During the Suharto regime, the kinship showed different orientation. They formed ties to further their political aspirations. Among these ties, PPPSBBI and TTKKDH were the most crucial formally structured organizations.

Both ulama and jawara are subcultures of the complete culture which make up Bantenese culture. Ulama are well known as public figures in the socio-religious aspect, while jawara deal mainly with society in the social institutions of the Bantenese. Even though ulama and jawara played different roles during the New Order era, the integration between them through PPPSBBI and Satkar Ulama led them to be considered as belonging to the social elite within Bantenese society.

Ulama and jawara are the source of informal traditional leadership, particularly in villages. Ulama represent the leadership in knowledge, while jawara represent the leadership regards to braveness and physicmagical power. This kind of leadership cannot be neglected, and in fact it can be traced back to the Sultanate period. The long history of rebellions in Banten led the Bantenese to possess a unique character which mainly characterized by ulama and jawara. Therefore, the relationship between ulama and jawara has two special characteristics they are the integrative and the disintegrative characteristic.

In the integrative social relationship, jawara need ulama as religious figures as well as for magical power. Ulama are seen as the most important legitimizing tool in jawara's leadership. Without ulama's

45 Ibid., pp. 44-53; Wilson, The Politics of Inner Power, p. 245; and Sunatra, Integrasi dan Konflik, pp. 100-101. 
support, jawara may have difficulties in becoming informal leaders. In the Bantenese society, which consider religion as guidance, approval from ulama will lead the society in choosing the leaders.

The dependence of Jawara on ulama is in issues of magical sources. It is widely believed in Banten that ulama possess 'Islamic magic' and that jawara gain their fighting skills from ulama. Hence, many jawara consider themselves as servants of ulama. On the other hand, ulama have several interests in jawara, mainly their physical and material support. Jawara who ask for martial arts and magic from ulama will surely give material compensation, such as money or valuable gifts, which are known as salawat. Giving salawat to ulama is meant as a ransoming of ulama's blessing given to jawara. ${ }^{46}$

It can be argued that the unique relationship between ulama and jawara obviously occured during the New Order era. According to Bourchier, Golkar utilized its affiliated associations, such as the Indonesian Renewal Youth Organisation (AMPI-Angkatan Muda Pembaharuan Indonesia), National Committee for Indonesian Youth (KNPI-Komite Nasional Pemuda Indonesia) and Siliwangi Youth (AMSAngkatan Muda Siliwangi) to secure support for the party (Bourchier, 1994). In Banten, where local politics was dominated by ulama and jawara, they made use of Satkar Ulama ${ }^{47}$ and PPPSBBI to gain victories. In this respect Golkar mirrored the tactics used by the PKI. They found out that the feelings of the Bantenese towards ulama were those of respect, while towards jawara they were a mixture of fear and respect. Therefore, to a large extent the integration between ulamajawara and the people could happen due to the support of almost all of the elements in Banten who believed in the power of the two social groups, and respected them up to recent days, as well.

\section{Conclusion}

As the important element in Bantenese society, the emergence of jawara is still questioned up to this day. However, the background that leads to the emergence of jawara can be traced back to the early nineteenth century. The changing pattern of the local hierarchy due to

\footnotetext{
46 Tihami, Kiai dan Jawara di Banten, p. 103.

${ }^{47}$ For the involvement of Mathla'ul Anwar, one of the largest Muslim mass-based organizations in Indonesia, in Golkar, see Didin Nurul Rosidin, From Kampung to Kota: a Study of the Transformation of Mathla'ul Anwar 1916-1998 (Unpublished Ph.D. thesis, Leiden University, 2007).
} 
the Dutch colonial government in Banten can be seen as the main factor in the emergence of the jawara. The attempts done by the Dutch to create a centralistic government, and deny noblemen their previous position, which was considered higher in society, perhaps explains why there were so many resistances to the Dutch in Banten in the nineteenth century.

These resistances are the first stage of the emergence of jawara. Together with other elements, jawara fought against colonial authorities, as a result of a hostile and aggressive attitude towards both the foreigners and the priyayi. It is remarkable to see that even though jawara often are seen as a negative social group, their involvement in the religious movements marks their ambiguous relationship with the rural inhabitants to whom they are both feared and admired.

The New Order regime under Suharto marked a long period of an authoritarian centralistic government where local authorities were forced to form patron-client relationships. In fact, under this regime the political domination of the state over society extended enormously. Even though many scholars believe that the government was successful in maintaining macro-economic stability, there were quite a few entrepreneurs who enjoyed this era of rapid development. The members of the Suharto family, the large Chinese-owned conglomerates, and major indigenous business groups were among the small number of entrepreneurs who had strong links to high government officials and their immediate families, and thus benefited from the patron-client relationships.

In Banten, the establishment of Satkar Ulama and Satkar Pendekar (later renamed as PPPSBBI) marked the ties between the state and the local society. I would argue that the ties, especially between the state and jawara are the most important ties among the patron-client relationships in Banten. Jawara were co-opted into the political machinery of Golkar, the ruling party. Through Tubagus Chasan Sochib, the general chairman of PPPSBBI, jawara could act as bridge between the military, bureaucracy and Golkar, where many governmental projects came into their possession, since they maintained closed patron-client relationships with the rulers. The ties lead prominent jawara to become local politicians, as well as entrepreneurs. The New Order offered them the opportunity to expand and maintain a regional network of patron-client ties. 
Meanwhile, Satkar Ulama and jawara, can also be seen as a determining factor in the process of local politics in Banten, where their influence went far beyond that of any other elements. The integration between ulama-jawara and the people led Golkar to achieve victories in Banten. In Banten, ulama and jawara were both respected and feared figures because of their physic-magical power, integrated they formed a unique combination supporting the New Order regime in Banten. This combination was strengthened by the support of local society to whom ulama were well-known figures in the socio-religious aspect, while jawara were considered by society as a social group within the Bantenese culture; thus the integration was able to exist for years, even up to the present day. [

\section{Bibliography}

\section{Books and Articles}

Abrori, Ahmad. "Perilaku Politik Jawara Banten dalam Proses Politik di Banten." Unpublished M.A. Thesis, Universitas Indonesia, 2003.

Arsip Nasional Republik Indonesia. Memori Serah Jabatan 1931-1940 Jawa Barat. Jakarta: Penerbitan Sumber-sumber Sejarah No. 11, 1980.

Atsushi, Ota. Changes of Regime and Social Dynamics in West Java: Society, State and the Outer World of Banten 1750-1830. Leiden and Boston: Brill, 2006.

Booth, Anne. The Indonesian Economy in the Nineteenth and Twentieth Centuries: a History of Missed Opportunities. Canberra: The Australian National University, 1998.

Bourchier, David. "Crime, Law and State Authority in Indonesia." in Arief Budiman (ed.). State and Civil Society in Indonesia. Clayton: Monash University Centre for Southeast Asian Studies, 1994.

Hidayat, Syarif. "'Shadow State'?: Business and Politics in the Province of Banten." in Henk Schulte Nordholt and Gerry van Klinken (eds.). Renegotiating Boundaries: Local Politics in Post-Subarto Indonesia. Leiden: KITLV Press, 2007. 
Hobsbawn, Eric. Primitive Rebels: Studies in Archaic Forms of Social Movement in the 19th and 20th Centuries. Manchester: Manchester University Press, 1959.

Hudaeri. Tasbih dan Golok. The Ministry of Religious Affairs, 2002.

Karomah, Atu. "Jawara dan Budaya Kekerasan pada Masyarakat Banten." Unpublished M.A. Thesis, Universitas Indonesia, 2004.

Kartodirdjo, Sartono. The Peasants 'Revolt of Banten in 1888, Its Conditions, Course, and Sequel: A Case Study of Social Movements in Indonesia. 'sGravenhage: Martinus Nijhoff, 1966.

Langenberg, Michael van, "The New Order State: Language, Ideology, Hegemony." in Arief Budiman (ed.). State and Civil Society in Indonesia. Clayton: Monash University Centre for Southeast Asian Studies, 1994.

Lubis, Nina. Banten dalam Lintasan Sejarab: Pergumulan antara Ulama dan Jawara. Jakarta: LP3ES, 2004.

Macintyre, Andrew. Business and Politics in Indonesia. North Sydney, NSW: Allen and Unwin, 1991.

Macintyre, Andrew. "State-Society Relations in New Order Indonesia: the Case of Business." in Arief Budiman (ed.). State and Civil Society in Indonesia. Clayton: Monash University Centre for Southeast Asian Studies, 1994.

Mansur, Khatib. Profil Haji Tubagus Chasan Sochib beserta Komentar 100 Tokoh Masyarakat Seputar Pendekar Banten. Jakarta: Pustaka Antara Utama, 2000.

Masaaki, Okamoto. "Local Politics in Decentralised Indonesia: the Governor General of Banten Province." IIAS Newsletter, No. 34 (2004).

Masaaki, Okamoto and Abdul Hamid. "Jawara in Power 1999-2007." Indonesia, 86 (October 2008): pp. 109-138.

Onghokham. "The Jago in Colonial Java, Ambivalent Champion of the People." in Andrew Turton and Shigeharu Tanabe (eds). History and Peasant Consciousness in South East Asia. Osaka: National Museum of Ethnology, 1984. 
Robison, Richard. "Culture, Politics, and Economy in the Political History of the New Order." in Benedict Anderson and Audrey Kahin (eds.). Interpreting Indonesian Politics: Thirteen Contributions to the Debate. Ithaca: Cornell Modern Indonesia Project Cornell University, 1982.

Robison, Richard. Indonesia: The Rise of Capital. Sydney: Allen and Unwin, 1986.

Suhaedi, H.S. "Jawara Banten: Kajian Sosial-Historis tentang Mobilitas Sosial Jawara.” Unpublished M.A. Thesis, Universitas Indonesia, 2006.

Sunatra. Integrasi dan Konflik: Kedudukan Politik Ulama-Jawara dalam Budaya Politik Lokal: Studi Kasus Kepemimpinan Informal Pedesaan di Banten Selatan. Unpublished Ph.D. Thesis, Universitas Padjadjaran, 1997.

Tihami, M.A. Kiai dan Jawara di Banten: Studi tentang Agama, Magi, dan Kepemimpinan di Desa Pasanggrahan Serang, Banten. Unpublished M.A. thesis, Universitas Indonesia, 1992.

Untoro, Heriyanti O. Kebesaran dan Tragedi Kota Banten. Jakarta: Yayasan Kota Kita, 2006.

Wessing, Robert, "The Position of the Baduj in the Larger West Javanese Society." Man, Vol. 12, No. 2 (1977): pp. 293-303.

Williams, Michael. Communism, Religion and Revolt in Banten. Athens: Ohio University Center for International Studies, 1990.

Wilson, Ian Douglas. "The Politics of Inner Power: The Practice of Pencak Silat in West Java.” Unpublished Ph.D. Thesis, Murdoch University, 2003. 